\title{
Pesticide Burial Grounds in Poland - Actuality Problem
}

\author{
Katarzyna Ignatowicz \\ 1 Faculty of Civil and Environmental Engineering, Bialystok University of Technology, 45A Wiejska St., 15-351 \\ Bialystok, Poland, e-mail: k.ignatowicz@pb.edu.pl
}

\begin{abstract}
Until $30^{\text {th }}$ June 2010, Poland liquidated a total of 180 burial grounds containing about 16.4 thousand Mg of expired pesticides and 97 warehouses containing 0.54 thousand $\mathrm{Mg}$ of waste. In the period from $1^{\text {st }}$ January 2011 till $31^{\text {st }}$ December 2013, a total of 28 burial grounds containing about 5.4 thousand $\mathrm{Mg}$ of obsolete pesticides were liquidated. Only 4 burial grounds containing about $278.43 \mathrm{Mg}$ wastes remained for liquidation on $31^{\text {st }}$ December 2013. Currently, 3 objects remained for the liquidation. The adopted course of action connected with burial grounds is to increase the involvement of the public administration to remove them in the provinces of Lower Silesia, Opole and Podlasie (finalization of conducted administrative proceedings and enforcement of their provisions).
\end{abstract}

Keywords: pesticide waste, burial grounds

\section{INTRODUCTION}

Landfills of obsolete plant protection means are among the most dangerous objects threatening the natural environment in Poland. Storage of expired pesticides started in the sixties. The problem of obsolete pesticides in the contemporary Cracow province was eliminated in June 1965 in all municipal cooperatives "Samopomoc Chłopska" by burying them in shallow pits dug in the ground occupied by these cooperatives. Due to the fact that over time, the amount of unused plant protection products increased, an instruction was developed in 1971, which - to a certain extent - regulated the construction of structures intended to deposit obsolete pesticides. The construction of burial grounds composed of circular curbs with a diameter of 1 to 2 meters and a depth of 3-4 $\mathrm{m}$ was recommended. Dozens of such wells were usually built at a single facility. In addition, to eliminate the expired pesticides, all kinds of military fortifications were fairly commonly used, from the firing bunkers from the Second World War through Prussian and Moscow defense forts of the nineteenth century (Biziuk, 2001; Biegańska et al., 2013, Siłowiecki, 1999).
The environmental conditions were not taken into account during the selection of the location for the burial grounds, with one possible exception: an attempt was made not to put them in the immediate vicinity of a village or agricultural buildings. Since the applicable law did not require conducting a hydro-geologic expertise for a given area at the building the structure, they were located on wastelands, sandy soils, or in old exploitation sites of natural aggregates. The fact that the sandy formations with very high permeability coefficients represent the areas of underground water resources, and the first groundwater level is taken mostly from the farm wells was not taken into account. At the beginning of the nineties, people started to talk about the possibility of environmental contamination by plant protection means emitted from the leaking burial grounds. Unfortunately, the first publications on the inventory of landfills impact on the environment were conducted in a very cursory manner and were limited to sampling from the surface of the soil and water in farm wells near the burial grounds and performing chemical analyzes of pesticides (Biziuk, 2001; Biegańska, 2013; Ignatowicz, 2008, Ignatowicz 2011). 


\section{TYPES OF BURIAL GROUNDS}

Most of burial grounds were closed in the period from 1975 to 1985 , and implementing the Law on Environmental Protection and Management made it virtually impossible to further use such facilities. Underground storage of various kinds of chemical waste has been for many years one of the most difficult environmental problems awaiting solution. In this situation, it was necessary to solve the problem of burial grounds in a comprehensive manner and in accordance with the current knowledge (Biziuk, 2001; Ignatowicz 2011; Ignatowicz, 2008; Morzycka, 2002; Environmental Report 2016). Most of burial grounds in Poland are built of concrete circles or cast concrete tanks. Concrete bunkers and other structures, e.g. silos for feed, have also been converted into burial grounds. Tar or glue was most often used as the insulation coverage (Biziuk, 2001). According to the design of the burial grounds, the excavation pits, well circles as well as old military facilities such as bunkers, fortifications, and concrete tanks, can be distinguished (Figure 1-2).

Depending on the structure and location of burial grounds, 5 toxicity categories can be enumerated:

- I hazard category - earth pits having no waterproofing insulation;

- II hazard category - burial grounds, the location of which threatens the water intake points and surface waters during leaking. This category also includes the burial grounds located in wetlands or endangered by floods;

- III hazard category - burial grounds not included in category I and II. They are charac- terized by soil and groundwater pollution due to the presence of expired pesticides in their neighborhood;

- IV hazard category - burial grounds belonging to the third type, in the form of military bunkers;

- V hazard category - other burial grounds.

\section{STOCKTAKING OF BURIAL GROUNDS}

The interest in burial grounds as objects dangerous to the environment began in the 1990s. It soon turned out that some of these objects are forgotten, the administrative changes of the 1970s led both to the dispersion of technical documentation and elimination of obsolete pesticides. As a result, it was necessary to start works on a cataloguing the burial grounds and execution of impact assessments of these facilities on the soil and water environment. The first stocktaking works were performed by The State Inspection for Plant Protection in 1993. In 1994, the inventory work on burial grounds and warehouses containing obsolete pesticides was begun, which was coupled with the field visions and detailed tests to the most dangerous objects. In 1998-1999, the Inspection carried out 108 controls of individual burial grounds in the country, completed with the release of the follow-up orders. They concerned, among others, cleaning up the burial grounds (mowing the grass, repairing the fence and marking), conducting the technical expertise of their tightness and testing of groundwater and water from piezometers (Biziuk, 2001; Biegańska, 2013, Ignatowicz, 2008; Siłowiecki, 1999).

b)

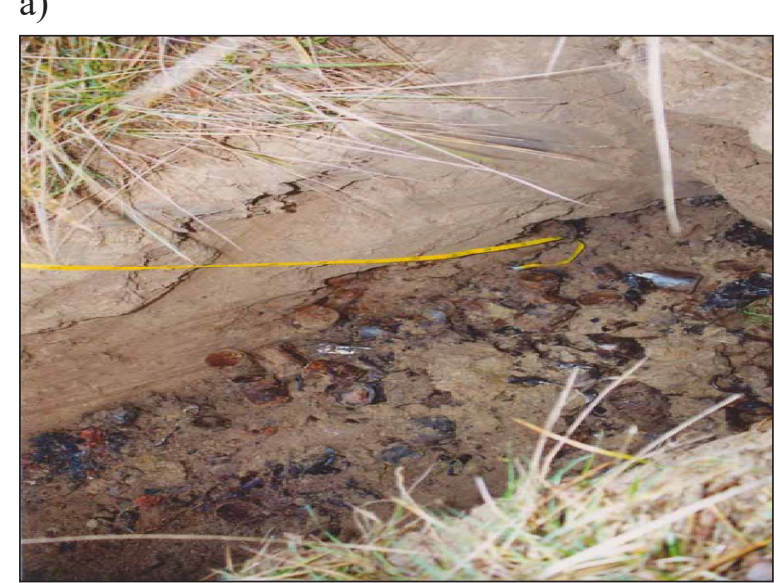

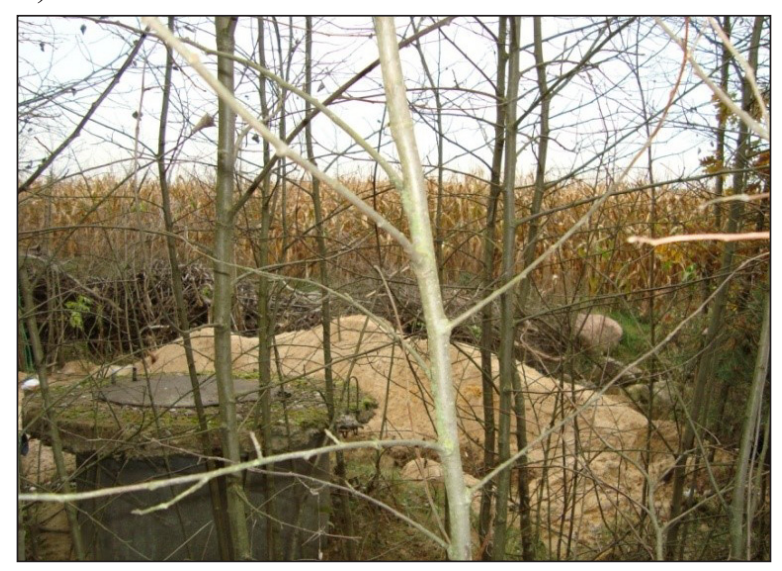

Figure 1. Earth pit and burial ground made of the well circles in the vicinity of maize plantation (author's own photograph) 
a)

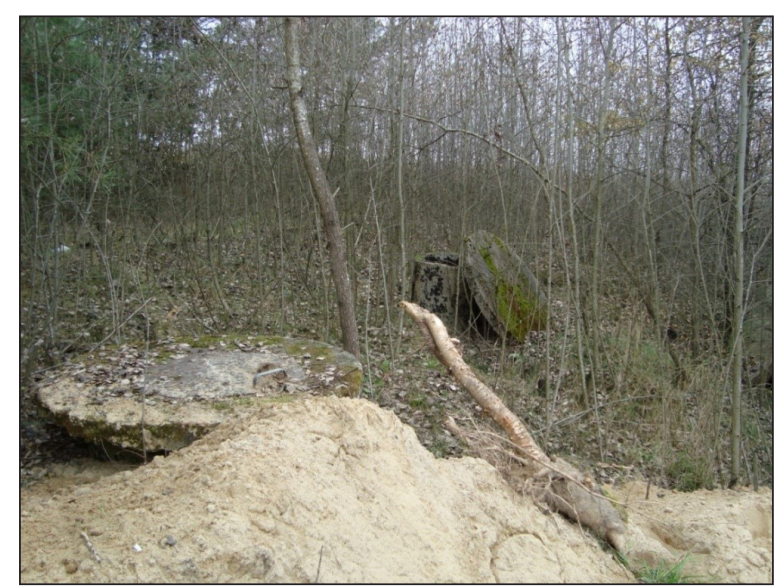

b)

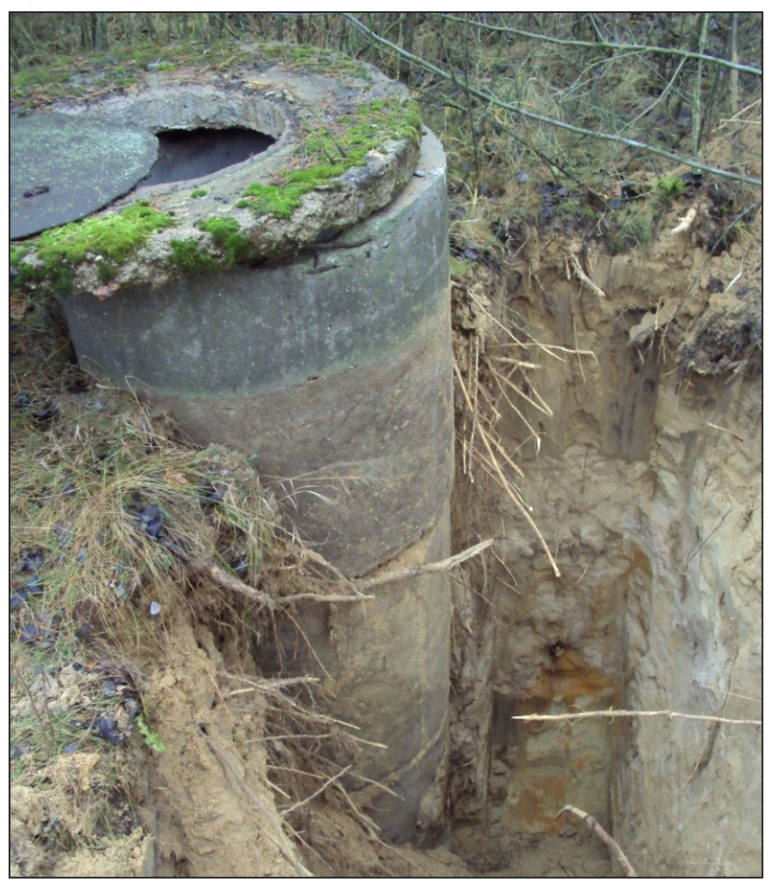

Figure 2. Well circles and removing the well excavation (author's own photograph)

According to the National Waste Management Plan in Poland, since 1965 there have been 340 burial grounds, where the expired plant protection means were deposited. This number may not be final, which may be indicated by e.g. finding a burial ground in Nisko, which has not yet been included in any databases. The largest burial grounds are located in the areas, where the stateowned farms dominated, for which the plant protection products are available at very low prices. It is estimated that the total amount of toxic substances dumped in these burial grounds is about 10000 tons of various agents. That value is approximate due to the lack of full documentation of burial grounds. It is estimated that another 800 "unofficial pits" contain at least 12000 tons of hazardous substances. To date, no attempts to accurately determine the quantity and composition of the "content" of all burial grounds were made. The information about the burial grounds in Poland shown in Table 1 is listed taking into account the administrative division into provinces, which will allow for more regional demonstration showing the location the existence of the landfills containing hazardous wastes. Most provinces have already tackled the burial grounds problem, but three such facilities still remain [Biziuk, 2001; Ignatowicz 2008).

Until $30^{\text {th }}$ June 2010, Poland liquidated a total of 180 burial grounds containing about 16.4 thousand $\mathrm{Mg}$ of obsolete pesticides and 97 warehouses containing 0.54 thousand $\mathrm{Mg}$ of wastes. From $1^{\text {st }}$ January 2011 till $31^{\text {st }}$ December 2013, a total of 28 burial grounds containing about 5.4 thousand $\mathrm{Mg}$ of expired plant protection means were liquidated. On $31^{\text {st }}$ December 2013, 4 burial grounds containing about $278.43 \mathrm{Mg}$ of wastes remained for liquidation. In accordance with the present situation (July 2015), 3 burial grounds are planned to be liquidated (Council of Minister, 2016; Ministry of the Environment. 2017):

1) Majdan village, Michałowo community, Podlasie province, amount of wastes $25.41 \mathrm{Mg}$;

2) Stare Julianowo village, Walim community, Lower Silesie province, amount of wastes about $165 \mathrm{Mg}$;

3) Brzeg city, Opole province, amount of wastes about $5 \mathrm{Mg}$.

\section{BURIAL GROUNDS IN PODLASIE PROVINCE}

Unsuitable pesticides and packaging are still a problem in the Podlasie province. According to the current data, in Podlasie region, there are 10 burial grounds ( 9 of which have already been liquidated) and 13 identified warehouses, in which unsuitable plant protection products in the amount of about $27 \mathrm{Mg}$ were collected (excluding the 
Table 1. Burial grounds in Poland in 2005-2017

\begin{tabular}{|l|c|c|c|c|}
\hline \multicolumn{1}{|c|}{ Year } & 2005 & 2010 & 2011 & 2017 \\
\hline Burial grounds & 140 & 31 & 32 & 3 \\
\hline Liquidated burial grounds & 16 & 208 & 210 & 239 \\
\hline Total & 156 & 239 & 242 & 242 \\
\hline
\end{tabular}

Table 2. Number of burial grounds in each province in 2004-2017

\begin{tabular}{|c|c|c|c|c|c|c|c|}
\hline \multirow[b]{2}{*}{ L.p. } & \multirow[b]{2}{*}{ Province } & \multicolumn{2}{|c|}{ Burial grounds 31.12.2004 } & \multicolumn{2}{|c|}{ Burial grounds 31.12.2005 } & \multirow{2}{*}{$\begin{array}{l}\text { Liquidated burial } \\
\text { grounds } 2005 \text { r. }\end{array}$} & \multirow{2}{*}{$\begin{array}{c}\text { Burial } \\
\text { grounds } \\
2017 \mathrm{r} \text {. }\end{array}$} \\
\hline & & $\begin{array}{l}\text { earth } \\
\text { pit }\end{array}$ & $\begin{array}{c}\text { constructional } \\
\text { object }\end{array}$ & $\begin{array}{l}\text { earth } \\
\text { pit }\end{array}$ & $\begin{array}{c}\text { constructional } \\
\text { object }\end{array}$ & & \\
\hline 1 & Dolnośląskie & 0 & $7\left(^{*}+1\right)$ & 0 & 7 & 1 & 1 \\
\hline 2 & $\begin{array}{l}\text { Kujawsko- } \\
\text { pomorskie }\end{array}$ & 0 & 17 & 0 & 15 & 2 & 0 \\
\hline 3 & Lubelskie & 0 & 0 & 0 & 0 & 0 & 0 \\
\hline 4 & Lubuskie & 0 & 0 & 0 & 0 & 0 & 0 \\
\hline 5 & Łódzkie & 5 & 17 & 5 & 16 & 1 & 0 \\
\hline 6 & Małopolskie & 20 & 1 & 20 & 1 & 0 & 0 \\
\hline 7 & Mazowieckie & 2 & 10 & 2 & 10 & 0 & 0 \\
\hline 8 & Opolskie & 0 & 2 & 0 & 2 & 0 & 1 \\
\hline 9 & Podkarpackie & 0 & 1 & 0 & 1 & 0 & 0 \\
\hline 10 & Podlaskie & 0 & 5 & 0 & 3 & 2 & 1 \\
\hline 11 & Pomorskie & 0 & 4 & 0 & 4 & 0 & 0 \\
\hline 12 & Śląskie & 1 & 5 & 1 & 5 & 0 & 0 \\
\hline 13 & Świętokrzyskie & 0 & 0 & 0 & 0 & 0 & 0 \\
\hline 14 & $\begin{array}{l}\text { Warmińsko- } \\
\text { mazurskie }\end{array}$ & 0 & 17 & 0 & 7 & 10 & 0 \\
\hline 15 & Wielkopolsie & 2 & 12 & 2 & 12 & 0 & 0 \\
\hline 16 & $\begin{array}{l}\text { Zachodnio- } \\
\text { pomorskie }\end{array}$ & 0 & 27 & 0 & 27 & 0 & 0 \\
\hline & Total & 30 & $\begin{array}{c}125 \\
\left({ }^{*}+1\right)\end{array}$ & 30 & 110 & 16 & 3 \\
\hline
\end{tabular}

packaging of plant protection products). In 2001, the burial grounds in Słochy Annopolskie and Wąsosz, in 2003 in Anusin, and in 2004 in ZbójnaDębniki, and only recently in Folwarki Tylwickie and Łapy, were liquidated. The wastes were transported to the waste incineration plant "Lobbe" in Dąbrowa Górnicza. Approximately, a total of 139 tons of waste was neutralized. The burial ground in Nowy Dwór was liquidated in November 2005. The plant protection means, along with packaging in the amount of $1.60 \mathrm{Mg}$ have been exported and disposed of by Przedsiębiorstwo ProjektowoWdrożeniowe "AWAT" Ltd. in Warsaw. After waste removal, the room was cleaned and the entrance to the facility was permanently bricked. In the burial ground established in the sixties, comprising three military bunkers connected by corridors, a total of $182 \mathrm{Mg}$ of toxic wastes were stored. The liquidation of this burial ground was carried out in several stages. The last stage was completed in 2001. The remaining part of waste in the amount of $21.621 \mathrm{Mg}$ got from the burial ground was deported to incineration plant AGR Group in Germany.

According to the National Institute of Geology, in 2003 the number of burial grounds and warehouses with overdue pesticides in Poland amounted to 284. According to estimates of the Ministry of the Environment (prior to 2009), approximately $13.9 \mathrm{Mg}$ of hazardous waste was deposited in them. According to the stocktaking carried out in 2009 by Regional Directorates for Environmental Protection and updated data provided by Ministry of the Environment in July 2010 , this number increased almost two hundred times - up to $2567.81 \mathrm{Mg}$. In the West Pomeranian province alone, there are still 19 burial grounds, in which $1,010.9 \mathrm{Mg}$ of waste is deposited. On the other hand, in the Podlasie province, there are 10 burial grounds, containing $25.41 \mathrm{Mg}$ of pesticides. The status of the burial grounds construction is deteriorating from year to year. This results 
Table 3. Burial grounds in the Podlasie province

\begin{tabular}{|c|l|c|c|c|}
\hline L.p. & Liquidated burial grounds & Liquidated waste gross (Mg) & Liquidation costs (PLN) & Year \\
\hline 1 & Grajewo (Wąsosz) & 182.00 & 1413958.00 & 2001 \\
\hline 2 & Dębniki (Zbójna) & 138.74 & 562934.00 & 2005 \\
\hline 2 & Słochy Annopolskie & 455.00 & & 2001 \\
\hline 3 & Anusin & 54.30 & & 200.00 \\
\hline 5 & Nowy Dwór (Bielany) & 1.60 & & 2005 \\
\hline 6 & Folwarki Tylwickie & 26.934 & 83832.90 & $2012-2013$ \\
\hline 7 & Łapy & 83.023 & 312732.65 & 2012 \\
\hline 8 & Baciuty & & & $2012-2013$ \\
\hline 9 & Ryboły & 16.946 & 82732.40 & $2012-2013$ \\
\hline 10 & Majdan & & - \\
\hline
\end{tabular}

in a high risk and environmental pollution, and can also pose a danger to local residents, because the pollution emitted into the environment is not noticeable. This leads to the contamination of groundwater and surface water, as well as soils as a result of pesticide waste penetration from the leaking burial grounds. These leaks, after reaching the aquifer, are transported in the direction of groundwater flow and can be captured by the surface water. For this reason, measures are taken for the elimination of burial grounds, which should be conducted in a fair way and consistent with the current knowledge. Each object should be treated individually; hence, tests of natural waters quality are carried out to determine the contamination and migration of pesticides in the surrounding area. In the case of corrosion and structural damage of burial grounds, a constant flow of pollutants into the open waters does and will occur for many years [Ignatowicz, 2011; Environmental Report 2016; National plan 2014).

It is worth remembering that even after the liquidation of the burial ground, the effects of toxic substances storage will be observed for many years both in the soil and water. Therefore, there is a need to find ways to reduce the migration of pesticides within the environment and to implement the new solutions.

\section{CONCLUSIONS}

The total amount of obsolete pesticides in Poland is estimated at about $60000 \mathrm{Mg}$. The employees of the Ministry of Environment believe that construction of modern landfills, in which contents of the still existing burial grounds and warehouses would be put constitutes the best solution at the moment. Currently, burial grounds are subject to up to three ministries: agriculture, environment and health. Until $30^{\text {th }}$ June 2010, Poland liquidated a total of 180 burial grounds containing about 16.4 thousand $\mathrm{Mg}$ of expired pesticides and 97 warehouses containing 0.54 thousand $\mathrm{Mg}$ of waste. In the period from $1^{\text {st }}$ January 2011 till $31^{\text {st }}$ December 2013, a total of 28 burial grounds containing about 5.4 thousand $\mathrm{Mg}$ of obsolete pesticides were liquidated. Only 4 burial grounds containing about $278.43 \mathrm{Mg}$ wastes remained for liquidation on $31^{\text {st }}$ December 2013. Currently, 3 objects remained for the liquidation. The adopted course of action connected with burial grounds is to increase the involvement of the public administration to remove them in the provinces of Lower Silesia, Opole and Podlasie (finalization of conducted administrative proceedings and enforcement of their provisions).

\section{Acknowledgements}

The research was funded by Research Project conducted in the Department of Technology in Engineering and Environmental Protection BUTNo. S/WBiIŚ/3/2014.

\section{REFERENCES}

1. Biziuk M. 2001. Pesticides. Occurance, determination and disposal. WNT, Warszawa (in Polish).

2. Biegańska J., Harat A., Zyzak W., 2013. Disposal of plant health product waste from graveyards using detonation combustion. Inżynieria Ekologiczna, 33, 13-20 (in Polish).

3. Ignatowicz K., 2011. Metals content chosen for environmental component monitoring in graveyards, Fresen. Environ. Bull. 20(1a), 270-273.

4. Ignatowicz K., 2008. Sorption process for migration reduction of pesticides from graveyards. Archives of Environmental Protection, 34(3), 143-149. 
5. Morzycka B. 2002. Influence of burial grounds on the environment on the basis of examining water samples from water intakes and farm wells from the vicinity of burial grounds in podlaskie voivodship. Report 2001, Plant Protection Institute, Poznan.

6. Environmental Report of Podlaskie Province 2015. Environmental Monitoring Library, Białystok 2016 (in Polish).

7. National plan of waste management implementation in range of graveyards elimination. NIK 2014 (in Polish).
8. Siłowicki A. 1999. Cataloguing of plant health product waste. Institute of plant species protection (IOR) Białymstok, (GEF Project in Poland), (in Polish).

9. Council of Minister Act No. 88, 1st of July 2016 r. concerning National Plan of Waste Management (in Polish).

10. Ministry of the Environment https://www.mos. gov.pl/srodowisko/odpady/odpady-niebezpieczne/ (8.12.2017) (in Polish). 